\title{
Onko värillä väliä?
}

Sari Pietarila ${ }^{1}$, Hilkka Kämäräinen ${ }^{1}$, Heli Wahlroos ${ }^{1}$, Pirkko Taurén ${ }^{2}$

1) Savonia-ammattikorkeakoulu,PL 72,74101Iisalmi, etunimi.sukunimi@savonia.fi

2) Faba osk, Vantaa, PL 40,01301Vantaa, etunimi.sukunimi@faba.fi

\section{TIIVISTELMÄ}

Ayrshire on ollut pitkään Suomen yleisin lypsykarjarotu. Sen osuus maamme lypsylehmistä on kuitenkin vähentynyt jo pidemmän aikaa samalla kun holsteinin osuus on kasvanut. ProAgrian tuotosseurantatilastojen mukaan vuonna 2018 holsteinlehmien osuus $(49,6 \%)$ on jo suurempi kuin ayrshirelehmien osuus $(48,6 \%)$. Suomenkarjan osuus $(1,1 \%)$ on säilynyt pitkään samana. Tutkimuksen tarkoituksena oli löytää syitä, joiden takia ayrshiresta luovutaan, tai syitä, jotka saavat ayrshiren säilymään karjassa. Toimeksiantajana toimi Faba, joka on valtakunnallinen tuotantoeläinten jalostuspalveluita tarjoava yritys. Tutkimuksen tavoitteena oli auttaa pitämään ayrshirerotu elinvoimaisena Suomessa. Yhteisen jalostusohjelman myötä tavoite kosketti samalla kaikkia punaisia rotuja Pohjoismaissa. Tutkimus toteutettiin teemahaastattelumenetelmällä. Haastateltavat valittiin tuotosseurantaan kuuluvien, yli 100 lehmän tilojen joukosta koko Suomen alueelta. Haastateltavien valintaan vaikutti tilan koon lisäksi myös ayrshirelehmien osuuden muutos karjassa vuodesta 2012 vuoteen 2017. Puhelinhaastatteluja tehtiin 12. Tutkimuksen tuloksista kävi ilmi, että yksi suurimmista syistä ayrshiren vähentämiseen karjassa on huono utarerakenne. Tämä näkyy myös tuotosseurannan tuloksissa, joiden mukaan ayrshireja on poistettu huonon utarerakenteen takia selkeästi holsteinia enemmän. Muita esiin nousseita syitä olivat muun muassa ayrshiren alhaisempi maitotuotos ja sekakarjan ruokinnalliset haasteet. Tiloilla, joilla ayrshiren osuus ei ollut pienentynyt, rodun hyvistä ominaisuuksista nousi esiin erityisesti kestävyys. Tutkimuksesta selvisi myös, että ayrshiren osuutta vähentäneet tilat aikovat pääasiassa vähentää rodun osuutta myös jatkossa. Sen sijaan tilat, joilla ayrshiren osuus ei ollut vähentynyt, aikoivat pääasiassa säilyttää rodun osuuden ennallaan tai jopa lisätä sitä. Tätä kannattaa tulevaisuudessa hyödyntää rodun markkinoinnin kohdentamisessa. Vaikuttaa siltä, että ayrshiresta luovutaan tietoisesti, mutta sen osuuden säilyttämistä tai lisäämistä ei koeta tietoiseksi päätökseksi. Tutkimuksen tulosten mukaan sidosryhmät eivät juurikaan vaikuta rotujen valintaan vaan karjanomistajat kokevat tekevänsä päätökset itse. Pienen aineiston vuoksi tulosten perusteella ei voida tehdä yleistyksiä, tosin suuri osa tuloksista on yhteneväisiä tuotosseurannan tulosten kanssa.

Asiasanat: ayrshire, lypsykarjarodut, karjanjalostus

\section{Johdanto}

Suomessa nautakarjan pitoa oletetaan olleen ainakin 2000 vuotta. Jo 1500-1800-luvuilla maahan tuotiin erirotuisia nautoja karjapopulaation parantamiseksi paremman väen kartanoihin, mutta yleisemmin karjanjalostusta alettiin harjoittaa vasta 1800-luvulla (Maijala 1998).

Holstein on lypsykarjaroduista yleisin maailmalla ja myös Pohjoismaissa. Holsteinin lisäksi Pohjoismaissa yleisimpiä lypsykarjarotuja ovat punaiset rodut ja jersey (NAV 2018b). Näille kolmelle rodulle on kehitetty yhteispohjoismaiset jalostusohjelmat, joissa rotujen etuliitteenä on Viking (NAV 2018a). Pohjoismaissa punaisten rotujen kanta on maailman suurin. Näitä punaisia rotuja ovat Suomen ayrshire, Ruotsin punainen eli Svensk röd och vit boskap (SRB) ja Tanskan punainen eli Rød Dansk Malkerace (RDM) (NAV 2018b).

Ayrshire on pitkään ollut Suomen yleisin lypsykarjarotu, mutta sen osuus on vuosien saatossa vähentynyt. Ayrshiren osuuden pienentyessä holsteinin osuus on samanaikaisesti kasvanut. Muiden rotujen, kuten suomenkarjan, jerseyn, brown swissin ja montbeliardin, osuudet Suomen lypsykarjaroduissa ovat edellä mainittuihin valtarotuihin verrattuna marginaaliset (Nokka 2018). 
Ayrshiren osuuden vähenemisen ja holsteinin lisääntymisen syistä on paljon olettamuksia, joista suurimpana ehkä holsteinin korkeampi maitotuotos. Tässä tutkimuksessa selvitettiin lypsykarjatilojen todellisia syitä ja taustoja rodun valinnalle. Näin pyrittiin saamaan selville rodun valintaan vaikuttavia erityispiirteitä, joiden avulla ayrshire-populaatio saataisiin pidettyä elinvoimaisena. Työn toimeksiantaja on Faba, joka on valtakunnallinen tuotantoeläinten jalostuspalveluita tarjoava yritys.

Tutkimuksen tavoitteena oli edesauttaa ayrshiren säilymistä ja kehittämistä Suomessa ja punaisten rotujen yhteisen jalostusohjelman myötä myös Pohjoismaissa. Tarkoituksena oli kartoittaa tilojen tarkkoja syitä vaihtaa tai olla vaihtamatta ayrshire johonkin muuhun rotuun. Työn tuloksia voidaan hyödyntää punaisten rotujen osuuden säilyttämisessä tai jopa kasvattamisessa.

\section{Aineisto ja menetelmät}

Tutkimuksessa käytettiin menetelmänä teemahaastattelua, sillä haluttiin selvittää haastateltavien mielipiteitä ja mielikuvia syvällisesti ennalta valituista aihepiireistä. Haastateltavat valittiin tuotosseurantaan kuuluvien lypsykarjatilojen joukosta. Käytettävässä aineistossa oli tilojen lehmämäärät roduittain vuosina 2012 ja 2017. Ensin aineistosta karsittiin pois ne tilat, joilla oli vuonna 2017 alle 100 lehmää, sillä haastateltaviksi haluttiin suuria ja kehittyviä tiloja. Suuren tilan käsite on mielipidekysymys. Esimerkiksi yhden robotin tilaa ei kuitenkaan usein lasketa vielä suureksi tilaksi, joten kartoitettujen mielipiteiden perusteella rajaksi valikoitui 100 lehmää.

Suuret tilat jaettiin kahteen ryhmään. Toisessa ryhmässä olivat tilat, joiden ayrshire-rotuisten lehmien osuus oli vähentynyt enemmän kuin yhdeksän prosenttiyksikköä. Näin toiseen ryhmään jäivät tilat, joiden ayrshire-rotuisten lehmien osuus oli kasvanut tai pysynyt jokseenkin samana. Ryhmästä, jossa ayrshire oli vähentynyt, suodatettiin vielä tilat, joissa muutos oli yli 30 prosenttiyksikköä. Näiden tilojen joukosta poimittiin sattumanvaraisesti tiloja niin, että ne sijoittuivat karjanumeron perusteella ympäri Suomea. Toisesta ryhmästä poimittiin rotujakaumaltaan keskenään mahdollisimman erilaisia tiloja, jotka sijoittuivat karjanumeron perusteella ympäri Suomea. Sijainnin ottamisella huomioon vältettiin tilojen mahdollinen sijoittuminen pelkästään samalle maantieteelliselle alueelle. Hirsjärven ja Hurmeen (2014) mukaan teemahaastatteluja on tehtävä niin monta, että saadaan tarvittu tieto. Tässä tutkimuksessa pyrittiin yhteensä 15 haastatteluun.

Tutkimuksessa noudatettiin rehellisyyttä, huolellisuutta ja tarkkuutta työn eri vaiheissa. Haastateltavia kunnioitettiin kertomalla heille, mistä tutkimuksessa oli kyse ja antamalla heidän itse päättää, haluavatko he siihen osallistua. Haastatteluaineistoja ei luovutettu ulkopuolisille ja niitä käsiteltiin anonyymisti tietoturvaseikat huomioiden. Tutkimuksessa selvitettiin avoimesti haastateltujen mielipiteitä eikä yritetty osoittaa kumpaakaan rotua paremmaksi. Keskusteluissa vastaajien kanssa huomioitiin, etteivät tutkijan omat mielipiteet tai asenteet vaikuttaneet työn tuloksiin.

Ennen varsinaisia haastatteluja tehtiin testihaastattelu. Sen avulla saatiin selville haastattelun keskimääräinen kesto ja testattiin haastattelurungon toimivuutta. Varsinaisia haastatteluja tehtiin lopulta yhteensä 12, joista kahdeksan oli ayrshiren osuutta vähentäneiden tilojen joukosta ja neljä niiden tilojen joukosta, joiden ayrshiren osuus oli lisääntynyt tai säilynyt suurin piirtein samana. Tiloja valittiin aluksi lopullisia haastatteluja enemmän siltä varalta, että kaikki tilat eivät halua osallistua haastatteluun. Tämä osoittautui hyväksi toimintatavaksi, koska useisiin tiloihin ei saatu lainkaan yhteyttä ja kolme tilaa kieltäytyi haastattelusta.

Haastattelut toteutettiin puhelinhaastatteluina, koska maantieteellinen etäisyys haastattelijan ja haastateltavien välillä kasvoi jopa useisiin satoihin kilometreihin. Puhelinhaastatteluiden käyttökelpoisuudesta ollaan montaa mieltä, mutta niiden sanotaan kuitenkin sopivan puolistrukturoiduille haastatteluille, jollainen teemahaastattelukin on. Puhelinhaastattelut myös antavat joustavuutta haastattelun 
toteuttamiselle, sillä aikataulut haastattelijan ja haastateltavan välillä on usein helpompi saada sopimaan yhteen kuin kasvokkain tehtävässä haastattelussa (Hirsjärvi ja Hurme 2014, Ikonen 2017).

Jokaisesta haastattelusta laadittiin haastattelumuistio. Muistioiden purkamisen jälkeen niiden sisältö luokiteltiin kahteen eri luokkaan. Kvalitatiivisessa tutkimuksessa aineiston luokittelu on tärkeä osa analyysiä, sillä silloin aineiston eri osia voi vertailla keskenään ja mahdollisesti löytää jotain samankaltaisuuksia. Jos haastateltavia ei ole kovin montaa, olisi mahdollista tehdä päätelmät myös suoraan aineistosta (Hirsjärvi ja Hurme 2014). Tässä tutkimuksessa koettiin tärkeäksi keskustelun kirjaaminen ilman suorien päätelmien tekoa.

Tämän jälkeen aineistoa tulkittiin niin, että saman näkökulman omaava lukija voi löytää tekstistä samat asiat kuin tutkija. Kvalitatiivisessa tutkimuksessa tulkinnat ovat usein moninkertaisia, sillä tutkija tulkitsee haastateltavan omia tulkintoja ja tutkimuksen lukija tekee päätelmiä tutkijan näkemyksestä. Teemahaastattelu olisi mahdollista analysoida sekä kvalitatiivisia että kvantitatiivisia menetelmiä käyttäen (Hirsjärvi ja Hurme 2014). Tässä tapauksessa aineiston määrä oli kuitenkin niin pieni, että tilastollisten analyysien teko ei ollut järkevää.

\section{Tulokset}

Kaikki 12 haastateltua olivat maitotilallisia, joilla oli karjassaan rotuina ainakin ayrshirea ja holsteinia. Kaikilla tiloilla lehmät olivat pihattonavetassa. Kahdeksalla tilalla oli käytössään automaattilypsy ja neljällä asemalypsy. Haastateltavista kolme oli aloittanut maitotilayrittäjänä 2010-luvulla, kuusi 2000-luvulla, kaksi 1990-luvulla ja yksi oli aloittanut yrittämisen 1980-luvulla. Pisimpään yrittäjinä toimineilla oli tiedossa tiloille jo jatkajat, joten vaikuttaisi siltä, että haastateltujen tilat tulevat kehittymään ja jatkamaan toimintaa myös tulevaisuudessa, mikä oli tavoitteena kohderyhmää valitessa.

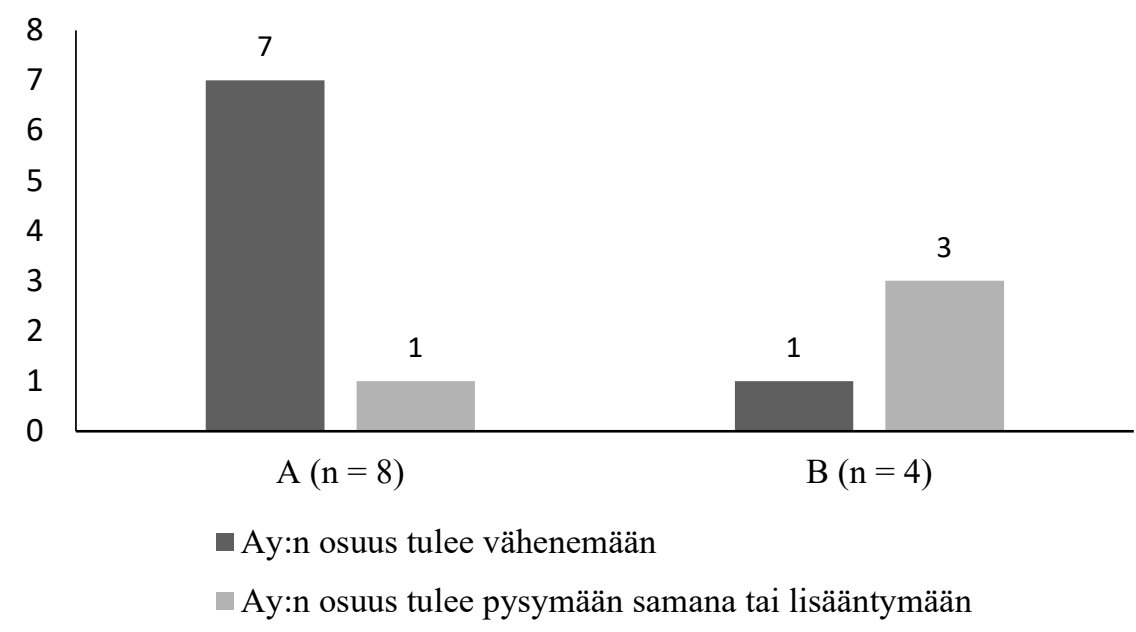

Kuva 1. Haastateltavien arvio tulevaisuuden rotujakaumasta

Tilat luokiteltiin kahteen ryhmään jo niiden valinnan perusteinakin olleiden syiden perusteella. Ensimmäisessä ryhmässä (myöhemmin ryhmä A) olivat tilat, joiden ayrshiren osuus oli vähentynyt enemmän kuin 30 prosenttiyksikköä vuodesta 2012 vuoteen 2017 ja toisessa ryhmässä (myöhemmin ryhmä B) olivat tilat, joiden ayrshiren osuus oli kasvanut tai pysynyt keskimäärin samana vuodesta 2012 vuoteen 2017. Ryhmässä A oli kahdeksan tilaa ja ryhmässä B oli neljä tilaa. 
Haastatteluissa tiedusteltiin, miten tilan rotujakauman uskotaan muuttuvan tulevaisuudessa (Kuva 1). Ryhmässä B oli yksi tila, jossa ajateltiin ayrshiren osuuden pienenevän tulevaisuudessa. Tätä ei varsinaisesti tavoiteltu, mutta jostain syystä tilalla ayrshireista saatiin paljon sonnivasikoita, kun taas holsteinit tekivät lehmävasikoita, jolloin rotujakauma muuttuu itsestään.

\section{Nykyiseen rotujakaumaan päätyminen}

Tiedusteltaessa, onko nykyiseen rotujakaumaan päätyminen ollut tietoinen päätös, A-ryhmästä seitsemän vastaajaa oli sitä mieltä, että nykyisiin rotuihin oli päädytty tietoisesti ja yksi koki, että tilanteeseen oli ajauduttu. Ryhmästä B kaikki vastaajat kokivat ikään kuin ajautuneensa tilan nykyiseen rotujakaumaan. Monelle tilalle, joka koki ajautuneensa nykytilanteeseen, oli yhteistä se, että eläinmäärää kasvatettaessa ostoeläimillä ostettiin sitä rotua, jota sattui olemaan helposti tarjolla.

Ryhmän A vastaajista kaikki olivat jossain vaiheessa risteyttäneet ayrshirea holsteinilla ja tällä tavoin muuttaneet rotujakaumaa holstein-painotteiseksi. Yksi näistä tiloista ei ollut täysin tyytyväinen myöskään puhtaaseen holsteiniin, ja tavoitteena olivatkin kolmiroturisteytykset. Tämä tila oli ainoa vastaajista, joka ei siementänyt enää yhtään ayrshireista omalla rodullaan. B-ryhmästä yksi vastaaja kertoi eläinmäärää lisätessään risteyttäneensä ayrshirea holsteinilla, sillä silloin heillä oli tilasonnina holstein.

Yksi A-ryhmän vastaajista näki yhtenä syynä nykyiselle rotujakaumalle sen, että tilalla vaihdettiin jalostuspalveluita tarjoava yritys Fabasta Semexiin, koska heidän mielestään Faballa sonnit vaihtuivat liian nopeasti ja samalla ayrshiren rakenne alkoi pettää. Semexin holsteinien koettiin olevan hyviä, mutta ayrshirella oli vain rakennetta eikä maitoa. Tämä oli yksi syy, mikä sai vaihtamaan rotua ayrshiresta holsteiniin.

Kaikista vastaajista 11 koki, että eri sidosryhmillä, kuten esimerkiksi jalostusneuvojilla, robottiedustajilla tai muilla vastaavilla, ei ole ollut vaikutusta tilan nykyiseen rotujakaumaan. Rotupäätöksiä kerrottiin tehdyn omien kokemuksien ja maailmalla nähdyn perusteella. Kaksi tilaa kertoi rotuja risteyttäessään toimineensa nimenomaan jalostusneuvojien ohjeita vastaan ja yksi tila mainitsi joskus noudattaneen jalostusneuvojan suositusta montbeliardesta.

Ainoastaan yksi vastaaja kaikista ajatteli, että sidosryhmillä on periaatteessa ollut vaikutusta rotujen valintaan. Tämä vastaaja kuuluu ryhmään $A$, ja hän käytti jalostussuunnitelmien tekoon apunaan Altan ja Semexin jalostusneuvojia. Hän koki, että holstein on rotuna helpommin jalostettava kuin ayrshire. Tällä tilalla ayrshiren rakennetta oli ensin lähdetty parantamaan kanadalaisilla sonneilla, mutta rakenteen parantuessa tuotos ei pysynyt mukana. Tämä sai tilan aloittamaan ayrshiren risteyttämisen holsteinilla.

\section{Tavoiteltavat ominaisuudet lehmässä}

Kun kysyttiin, millainen tilan ihannelehmä on, eli millaista lehmää halutaan lypsää, eniten esiin nousivat Kuvassa 2 ilmenevät lehmän ominaisuudet. Lisäksi vastaajat mainitsivat muun muassa hyvän luonteen, hyvät jalat, maidon korkeat pitoisuudet ja matalat solut ja huomaamattomuuden. Robottitiloilla arvostettiin myös lehmän aktiivisuutta.

Tiedusteltaessa jalostuksen päätavoitteista kaksi B-ryhmän vastaajaa kertoi ayrshiren koon kasvattamisen ja holsteinin koon pienentämisen olevan tärkeimpiä tavoitteita. Myös yksi A-ryhmän vastaajista piti tärkeänä holsteinin koon maltillistamista. Viisi vastaajaa A-ryhmästä ja yksi B-ryhmästä piti tuotosta yhtenä 


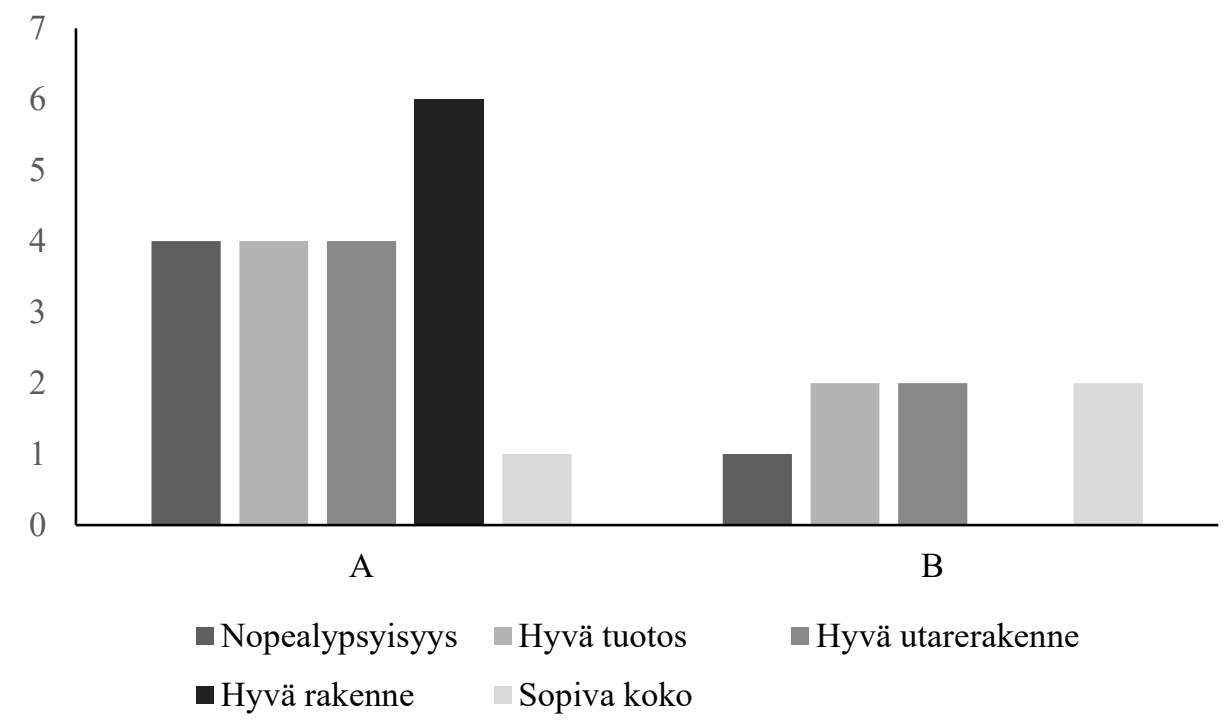

Kuva 2. Ihannelehmän ominaisuuksia (A $n=8$, B $n=4)$

tärkeimmistä tavoitteista. Kolme A-ryhmän vastaajista piti myös lypsynopeutta tärkeänä jalostustavoitteena. Utareterveys nousi esiin kolmella A-ryhmän vastaajista ja kahdella B-ryhmän vastaajista. Utarerakennetta yhtenä tärkeimmistä jalostustavoitteista piti kaksi vastaajaa A-ryhmästä ja yksi B-ryhmästä. Kestävyyttä piti tärkeänä jalostustavoitteena kolme vastaajaa A-ryhmästä ja yksi B-ryhmästä. Muita esiin nousseita tärkeitä jalostustavoitteita olivat muun muassa luonne, jalat, rakenne, karjan tasaisuus sekä robottiaktiivisuus.

\section{Sekakarjan haasteet}

Kolme A-ryhmän vastaajista koki sekakarjan aiheuttavan ongelmia karjan ruokinnassa. Yksi B-ryhmän vastaajista koki ruokinnan aiheuttavan haasteita, mutta ei ongelmaksi asti. Näillä tiloilla ruokittiin kaikki lypsävät samalla appeella ja koettiin, että ayrshire lihoo helposti sillä ruokinnalla, jolla holsteinin kuntoluokka pysyy hyvänä. Yksi tiloista näki, että ayrshiren loppulypsykauden lihominen vaikuttaa negatiivisesti myös seuraavaan lypsykauteen ja tiinehtyvyyteen. Tällä tilalla sekakarjan ruokinnan haasteellisuus olikin yksi suurimmista syistä ayrshiresta luopumiseen.

Viisi vastaajaa A-ryhmästä ja kolme B-ryhmästä koki, että sekakarja ei aiheuta ongelmia karjan ruokinnassa. Näistä A-ryhmän vastaajista kaksi tilaa kertoi ruokinnan olleen ennen haasteellista ayrshiren lihomisen takia, mutta nykyään karjoissa ovat jäljellä enää vain ne ayrshiret, jotka pärjäävät samalla ruokinnalla holsteinin kanssa. Yhdellä näistä A-ryhmän tiloista oli käytössään erillisruokinta, joten väkirehun määrää pystyttiin säätämään kioskeilla kullekin lehmälle sopivaksi. Kaksi B-ryhmän tiloista kertoi olevansa luomutiloja. Luomutilojen sääntely rajoittaa lehmille annettavan väkirehun määrää. Tämä saattaa olla yksi syy siihen, miksi sekakarjan ruokinta ei heillä aiheuta ongelmia.

Kolme vastaajaa kummastakin ryhmästä koki, että sekakarja ei aiheuta haasteita eläintilojen osalta. Näistä B-ryhmän vastaajista yhdellä lehmät oli jaettu roduittain ryhmiin, jolloin esimerkiksi niskaputkien säädöt ovat molemmilla ryhmillä omansa. Muut B-ryhmän vastaajat kokivat karjan olevan suhteellisen tasakokoista tai koon ei nähty olevan rotukohtainen ongelma. Viisi vastaajaa A-ryhmästä ja yksi vastaaja B-ryhmästä ajatteli, että sekakarja aiheutti eläintiloissa haasteita. Ongelmia koettiin olevan niin isoilla holsteineilla kuin myös pienillä ayrshireilla. Erityisen suuret holsteinit eivät meinaa mahtua parsiin tai robottiin ja pienet ayrshiret sotkevat parsia, pääsevät heilumaan lypsyllä tai menevät luvattomiin paikkoihin. Näillä tiloilla pääasiassa tavoiteltiinkin karjan tasakokoisuutta. 


\section{Ayrshiren ominaisuudet}

Tiedusteltaessa mielipiteitä ja ajatuksia ayrshiren utarerakenteesta päällimmäisenä nousi esiin se, että ongelmia on ollut paljon. Ryhmän A vastaajista kolme kertoi ayrshiren utarerakenteen olleen ennen heikompi ja nyt karjassa jäljellä olevilla on ihan hyviä utareita. Utarerakenteen koettiin olleen yksi suurimmista ayrshiren poiston syistä. Yksi vastaajista koki, että ennen ei ayrshirella löytynyt hyvää utarerakennetta ja vaikka nykyään sukulinjoja penkomalla hyvää utaretta voisi löytyä, ei enää kiinnosta edes etsiä. Ryhmässä A kaksi vastaajaa koki ayrshiren vedinten pienuuden ongelmaksi, yksi vastaaja B-ryhmästä moitti lyhyitä ja pieniä vetimiä. Kolme vastaajaa A-ryhmästä koki ayrshiren utareen repsahtavan helposti, mikä aiheuttaa ongelmia lypsyssä ja lehmä ei kestä niin hyvin lypsykaudesta toiseen. Kaksi vastaajaa Aryhmästä ja yksi vastaaja B-ryhmästä koki utareen pienen maavaran aiheuttavan haasteita. Tähän todettiin utarerakenteen lisäksi vaikuttavan myös sen, että ayrshiren jalat ovat lyhyet. Kahden B-ryhmän edustajan mukaan ayrshiren ja holsteinin utarerakenteessa ole juurikaan eroa. Yksi B-ryhmän vastaaja halusi parantaa ayrshiren takautareen leveyttä ja utarekudoslaatua, lihasutaretta haluttiin välttää. Myös yksi A-ryhmän vastaajista mainitsi lihasutareen yhdeksi ayrshiren utareen ongelmista. Yksi B-ryhmän vastaajista ajatteli, että holsteinilla utareen takakiinnitys on parempi kuin ayrshirella, mutta etukiinnitys ayrshirella puolestaan holsteinia parempi.

Ayrshiren jalkarakenteesta kysyttäessä kuusi vastaajaa ryhmästä A oli sitä mieltä, että ayrshiren ja holsteinin jaloissa ei ole eroa eikä jalkarakenteessa nähty ongelmaa. Yksi heistä koki ayrshiren jalkojen muuttuneen vuosien varrella kevyemmiksi ja litteäluisemmiksi. Kaksi vastaajaa ryhmästä A toivoi ayrshiren jalkoihin lisää korkeutta, jotta utareella olisi enemmän maavaraa. Yksi A-ryhmän vastaajista ajatteli, että ehkä ayrshirella on ollut enemmän jalkaongelmia kuin holsteinilla. Ryhmän B vastaajista kaksi koki jalkarakenteen parantuneen paljon entisestä, koska siihen on kiinnitetty tilakohtaisessa jalostuksessa paljon huomiota. Kaksi vastaajaa B ryhmästä ajatteli ayrshiren jalkarakenteen olevan parempi kuin holsteinilla ja yksi vastaaja koki, että ayrshiret ovat ehkä vähän jalkavikaisempia kuin holsteinit.

Kun tiedusteltiin mielipiteitä ayrshiren koosta, neljä vastaajaa ryhmästä A koki ayrshiren olevan sopivankokoinen. Yksi A-ryhmän vastaajista ja kaikki B-ryhmän vastaajista pitivät yksittäisen lehmän kokoa tärkeämpänä koko karjan tasakokoisuutta. Eräs vastaaja A-ryhmästä ajatteli, että tasakokoista ayrshire-karjaa on hankala saada, sillä ayrshire periyttää pientä kokoa helposti eteenpäin. Liian pieneksi ayrshiren koki kaksi vastaajaa kummastakin ryhmästä. Joillakin tiloilla ajateltiin myös vasikka- ja hiehoajan heikon ruokinnan vaikuttaneen siihen, että lehmistä on tullut pieniä.

Utare- ja sorkkaterveydestä tiedusteltaessa seitsemän vastaajaa ryhmästä A koki, että rotujen välillä ei ole eroja eikä niissä ole mainittavia ongelmia. Yksi vastaaja A-ryhmästä ajatteli, että ayrshire on yleisestikin holsteinia terveempi ja näin myös utareterveyden kohdalla. Yksi A-ryhmän vastaaja koki ayrshiren sorkkaterveyden olevan huonompi kuin holsteinilla ja mietti siihen syyksi raskaampaa rakennetta ja lihavuutta. Ryhmän B vastaajista kaksi koki ayrshiren utareterveyden olevan hiukan parempi kuin holsteinilla, yksi ajatteli, että ayrshirella on enemmän ongelmia utareterveydessä ja yksi puolestaan oli sitä mieltä, että rotujen välillä ei ole eroja. Utarerakenteen mainittiin yhtenä syynä ongelmiin utareterveydessä. Ryhmän B vastaajista yksi ajatteli ayrshiren sorkkaterveyden olevan parempi kuin holsteinilla, kaksi koki, että ayrshiren sorkkia pitää hoitaa enemmän kuin holsteinin ja yksi ei nähnyt rotujen välillä eroja. Yleisesti ayrshiren terveydestä tuli ilmi kahden vastaajan kohdalla, että ayrshire on holsteiniin verrattuna sitkeämpi: "Ayrshiren pitää olla jo todella sairas ennen kuin se oireilee ulospäin ja holstein ei samassa tilanteessa enää edes yritä”.

Ayrshiren kestävyydestä A-ryhmästä kolme ajatteli, että holsteinit kestävät ayrshirea paremmin. Syyksi tähän ajateltiin muun muassa sitä, että ayrshireja on joutunut poistamaan paljon utarerakenteen ja lypsettävyyden takia. Viisi vastaajaa A-ryhmästä koki ayrshiren olevan kestävä ja kolme heistä ajatteli sen 
olevan jopa kestävämpi kuin holstein. Ryhmän B vastaajista kolme oli sitä mieltä, että ayrshire on kestävämpi kuin holstein. Yksi vastaaja B-ryhmästä ei nähnyt rotujen välillä eroa.

Kolme A-ryhmän vastaajista koki, että heillä ayrshiren tuotos ei ole ollut ongelma. Yksi heistä totesi tuotoksen vaihteluvälin olevan turhan iso, holsteinilla tuotos on tasaisempi. Viisi vastaajaa A-ryhmästä kertoi ayrshiren tuotoksen olevan holsteinia matalampi. Yksi heistä koki maidon hinnoittelun kannustavan litrojen tuottamiseen, ja holsteinin tuotos on parempi. Hän totesi, että jos hinnoittelu muuttuu enemmän pitoisuuksia suosivaksi, niin silloin voi olla, että "rotujakaumaakin muutetaan vähemmän mustaksi". Ryhmässä B yksi vastaaja kertoi ayrshiren tuotoksen olevan tilalla vain vähän holsteinia matalampi, muilla ayrshiren tuotos oli selvästi pienempi kuin holsteinilla. Suurin osa kaikista haastateltavista ajatteli, että maidon pitoisuudet ovat ayrshirella holsteinia paremmat. Yhdellä tilalla pitoisuuksissa rotujen välillä ei ollut juurikaan eroja ja jotkut eivät olleet kiinnittäneet asiaan huomiota.

\section{Johtopäätökset}

Tutkimuksen tavoitteena oli auttaa pitämään ayrshire elinvoimaisena rotuna. Tätä varten kartoitettiin syitä, joiden takia ayrshiresta on luovuttu ja syitä, joiden vuoksi sitä on edelleen karjassa. Tuloksista nousi esiin se, että ayrshiresta luopumiseen oli vaikuttanut monia syitä, mutta eniten ongelmat utarerakenteessa. Tämä näkyy myös tuotosseurannan tuloksissa, joiden mukaan ayrshireja on poistettu huonon utarerakenteen takia selkeästi holsteinia enemmän (Kuva 3). Niiden tilojen kohdalla, joilla ayrshiren osuus ei ollut laskenut, nousi usein esiin ayrshiren hyvä kestävyys. Tämä on yhteneväinen tuotosseurannan tuloksien kanssa, jos kestävyyttä ajatellaan keskipoikimakerran kannalta, sillä se on ayrshirella parempi kuin holsteinilla. Jos taas kestävyyttä mitataan energiakorjattuna maitomääränä elinpäivää kohden, on holstein siinä hiukan ayrshirea edellä. Tähän lienee syynä holsteinin parempi tuotos. Holstein siis tuottaa enemmän, mutta ayrshirella on tuotospäiviä enemmän.

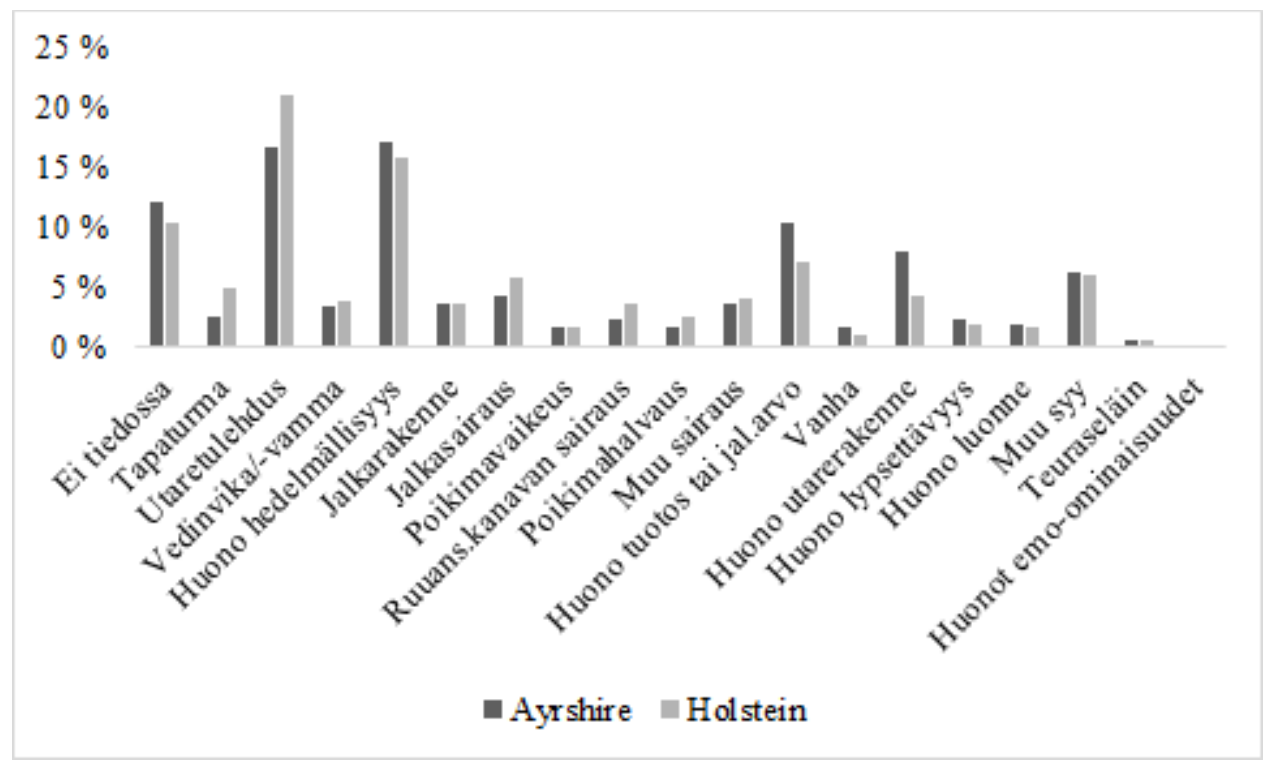

Kuva 3. Ayrshiren ja holsteinin poiston syyt vuonna 2017 (ProAgria tuotosseuranta 2018)

Tutkimuksen tuloksien pohjalta voidaan todeta, että pääasiassa niillä tiloilla, joilla ayrshiren osuus karjassa oli viime vuosina vähentynyt (ryhmä $\mathrm{A}$ ), rodun osuus tulee vähentymään myös tulevaisuudessa. Ne tilat puolestaan, joilla ayrshiren osuus oli säilynyt samana tai lisääntynyt (ryhmä B), aikovat pääasiassa pitää osuuden jatkossakin samana tai jopa lisätä sitä. Tämä noudattaa samaa kaavaa, joka oli nähtävissä myös 
aineistosta, jonka pohjalta haastateltavat poimittiin. Tuloksista oli myös selkeästi havaittavissa, että ryhmä B suhtautuu ayrshireen kokonaisuudessaan myönteisemmin kuin ryhmä A.

Tulosten mukaan suurin osa ryhmän A tiloista koki, että nykyiseen rotujakaumaan on päädytty tietoisesti ja kaikki ryhmän B tiloista koki ikään kuin ajautuneensa nykyiseen rotujakaumaan. Vaikuttaa siltä, että ayrshiresta luovutaan tietoisesti, mutta sen osuuden säilyttämistä tai lisäämistä ei koeta tietoiseksi päätökseksi. Tämä oli toisaalta odotettavaa, sillä jos on ongelmia, niitä poistetaan yleensä tietoisesti. Jos taas ongelmia ei ole, ei asiaa tule edes ajateltua.

Kysyttäessä minkälaista lehmää tilalla halutaan lypsää, nousi A-ryhmässä usein esiin, että lehmällä tulee olla hyvä rakenne. B-ryhmäläisistä puolestaan kukaan ei ilmoittanut hyvää rakennetta ihannelehmän ominaisuudeksi. Oletettavasti B-ryhmässäkin lehmän hyvää rakennetta arvostetaan, mutta A-ryhmäläiset kokivat sen selkeästi tärkeämmäksi, koska osasivat mainita sen. Koska rakenne on yksi tärkeimmistä jalostettavista ominaisuuksista ja ayrshiren jalostuksessa sitä vielä painotetaan vähän enemmän kuin holsteinilla, on mielenkiintoista, että ryhmä $\mathrm{B}$, joka pitää sisällään nimenomaan ayrshirekarjoja, ei tullut tätä maininneeksi. Toisaalta, koska A-ryhmäläiset olivat usein kamppailleet rakenneongelmien kanssa ja ne olivat usein osasyynä ayrshiren vähentämiseen, heillä asia oli ehkä tuoreena mielessään ja kokivat sen tärkeäksi. Tärkeimpien jalostustavoitteiden kohdalla hyvä rakenne ei kuitenkaan noussut erityisen monella vastaajalla esille. Voisiko tästä päätellä, että hyvää rakennetta pidetään karjassa tärkeänä, mutta tällä hetkellä sitä ei tarvitse erityisesti tavoitella?

Tuloksista on pääteltävissä, että karjan halutaan olevan rodusta riippumatta tasakokoinen, sillä yhtä lailla kuin ayrshiren pienempi koko saattoi aiheuttaa haasteita sekakarjassa, niin liian iso holstein voi olla myös ongelmallinen. Myös ayrshiren koosta mielipiteitä tiedusteltaessa nousi esiin karjan tasakokoisuuden tärkeys. Suurimmalla osalla tiloista sekakarjan ruokinnan ei nähty nykyään aiheuttavan ongelmia. Vastaajissa oli kuitenkin tiloja, joissa ayrshirea oli karsiutunut senkin perusteella, että osa niistä lihoi samalla ruokinnalla kuin holstein.

Tutkimuksen tulosten mukaan A-ryhmän utare- ja sorkkaterveydessä ei ole juuri eroa ayrshiren ja holsteinin välillä, mutta erityisesti B-ryhmässä vastauksissa oli kuitenkin hajontaa. Vain muutama kaikista vastaajista ajatteli ayrshiren terveyden olevan holsteinia parempi, vaikka tuotosseurannan tuloksien mukaan ayrshirea on hoidettu keskimäärin holsteinia vähemmän eri sairauksien takia. Tähän voi olla syynä se, että terveysominaisuuksien periytyvyys on pieni ja ympäristö vaikuttaa niihin paljon.

\section{Kirjallisuus}

Hirsjärvi, S. \& Hurme, H. 2014. Tutkimushaastattelu. Teemahaastattelun teoria ja käytäntö. Helsinki: Gaudeamus. $212 \mathrm{~s}$.

Ikonen, H. 2017. Puhelinhaastattelu. Teoksessa Hyvärinen, M, Nikander, P \& Ruusuvuori, J. (toim.). Tutkimushaastattelun käsikirja. Tampere: Kustannusosakeyhtiö Vastapaino. s. 270-284.

NAV 2018a. NTM - Pohjoismainen kokonaisjalostusarvo. Nordic Cattle Genetic Evaluation. Viitattu 2018-01-26. http://www.nordicebv.info/fi/ntm-nordic-total-merit-2/

NAV 2018b. Pohjoismainen lypsykarja. Nordic Cattle Genetic Evaluation. Viitattu 2018-01-09. http:/www.nordicebv.info/fi/suomi-nordic-dairy-cattle/

Nokka, S. 2018. Lypsykarjan tuotosseurannan tulokset 2017. ProAgria Keskusten Liitto. Viitattu 2018-04-12. https://www.proagria.fi/sites/default/files/attachment/lypsykarjan_ tuotosseurannan_tulokset_2017_sanna_nokka.pdf

Maijala, K. 1998. Jalostustyöllä tulosta, 100 vuotta naudan- ja sianjalostusta. Vantaa: Suomen Kotieläinjalostusosuuskunta. $74 \mathrm{~s}$. 